\title{
La meditación de la muerte en los penitentes de la pintura española del siglo de oro. Ascetas, melancólicos y místicos
}

\author{
Palma Martínez-Burgos $\mathrm{G} .{ }^{a}$ *
}

\begin{abstract}
RESUMEN
ABSTRACT

A través de este articulo estudiamos

Throug this article we know the uno de los apartados iconográficos más importantes de la pintura española del Siglo de Oro, el de los santos penitentes y su meditación en torno a la muerte. Concebidos como "vanitas", en ellos hallamos los diversos componentes de la oración: el asceta, el melancólico y el místico. De este modo, sus imágenes se convirtieron en verdaderos iconographic subject of penitents and hits death's meditation along the spanish painting of Gold Century. Thought as "vanitas", we find the several prayer's degrees: the ascetic, the melancolic and the mistic prayer. So, ours pictures were real "haandbooks of christian perfection».
\end{abstract} “manuales de perfección cristiana».

El deseo vehemente de la muerte, su añoranza y su nostalgia impregna toda una corriente poética desde finales del siglo xv. Desde entonces, la contraposición vida-muerte es un juego permanente que anima muchos textos literarios y muchas de las imágenes pictóricas producidas a lo largo de la España de los siglos XVI y XVII. El "vivo sin vivir en mí, y muero porque no muero..." de santa Teresa es, sin duda, un lugar común del pensamiento moderno, un tópico, desde el momento en el que refleja la forma de compenetrarse, trágica y morbosa, de la vida con la muerte reforzando y modificando el sentido de ambas. Sin embargo, el terreno ideológico en el que

\footnotetext{
* Facultad de Humanidades de Toledo. UC-LM.
} 
este fenómeno se produce había sido cuidadosamente preparado por la espiritualidad tardomedieval. La atracción por lo macabro que traducían las burlescas danzas de la muerte se irá tiñendo de una nueva concepción apoyada en una serie de tratados encaminados a una reflexión más ética y acorde al cristianismo interiorizado que irá caracterizando la "devotio moderna".

Por toda Europa, desde los años finales del siglo xv y a lo largo de la centuria siguiente, se reeditan los escritos de san Jerónimo, de san Agustín o de san Vicente Ferrer. Igualmente, obras como La Vita Christi del cartujo Ludolfo de Sajonia, el Contemptus Mundi de Tomás de Kempis y las Meditaciones sobre la vida de Cristo de san Buenaventura vuelven a publicarse, amén de un largo ecétera lo que facilitará el cambio en la sensibilidad espiritual. Todos son textos destinados a ayudar a la meditación y a la interiorización de la fe en lo que supone un acercamiento al ideal de la nueva devoción cristiana. Todos se configuran como manuales dirigidos a ejercitar la facultad contemplativa y se centran especialmente en la meditación de la hora final. “...Bienaventurado el que tiene siempre la hora de su muerte ante sus ojos y se apareja cada día a morir...» avisan las páginas del Eclesiástico .

Dentro de esta corriente de ascetismo cristiano distinguimos la mera preparación ad morten de la propia meditación sobre la muerte. Así, en paralelo a los numerosos ars moriendi que por doquier preparaban para la buena muerte, surgieron otro tipo de manuales abocados a la reflexión sobre lo efímero de la vida y de los bienes terrenales, la caducidad de nuestro tiempo frente a lo eterno del más allá, pues no debemos olvidar que la concepción cristiana del barroco es que sólo con la muerte comienza la verdadera vida. Esta "meditatio mortis" despliega todos los ingredientes propios de lo que dará en llamarse la "estética del desdén»: desprecio y renuncia de toda posesión terrenal, ansia de soledad e imitación de la pasión de Cristo lo que conlleva la mortificación sublimada, la visión del premio eterno y un sinfín de aspectos que tuvieron su reflejo en los símbolos que se forjaron en torno a este tema. Los diversos autores cristianos buscaron en el pensamiento de la muerte los resortes que movieran al fiel a enderezar su vida y con la amenaza del castigo eterno se potenció el drama de la agonia personal.

La consecuencia más evidente fue la aparición por doquier de las cofradías de disciplinantes, flagelantes y de la buena muerte, inspiradas en el terror del juicio final y de la posible condena. Pero no fue la única respuesta ya que en el terreno de la interiorización de la fe, la propia literatura

Tomás de Kempis. Contemptus mundi o menosprecio del mundo e imitación de Cristo, B.A.E. t. XI. Traducción de fray Luis de Granada, pág. 389. 
espiritual citada arriba creó un ambiente de exaltación de la imaginación y de los sentidos al servicio de la experiencia religiosa. Al sugerir una imagen mental, los manuales de meditación se contagian de ese deseo característico de la devocion moderna de hacer visible lo invisible incluyendo un extraordinario despliegue de detalles iconográficos con el fin de facilitar y ambientar de forma convincente la meditación. Siguiendo la tradición de la retórica clásica que concedía una enorme importancia a este aspecto ${ }^{2}$, se insiste en crear metáforas y establecer analogias que ayuden al fiel a caminar por las esferas de lo sobrenatural. Bajo la idea de que es conveniente aprender a morir varias veces en la vida para acertar el día de la muerte, los ejercicios espirituales ayudaban a tal propósito. Sea como fuere uno de los ejemplos más evidentes son las recomendaciones ignacianas en las que se recogen los pasos a seguir para la composición de lugar jesuítica. Cuando el objeto de la meditación es la propia muerte se dice que "Esta meditación debe hacerse con las ventanas cerradas, porque la oscuridad del lugar ayuda mucho a imprimir en el alma el horror de la muerte. Al mismo tiempo, es conveniente tener una calavera..." ${ }^{3}$. Así que una de las metáforas más recurrentes fue la de buscar la oscuridad de la noche como sinónimo de la que acompaña a la Parca y por la misma razón otros acudieron al paralelismo muerte y sueño. De esta manera quedaba forjada la imagen mental y el proceso personal, individualizado e íntimo de acercamiento a la muerte, de cotidianeidad con determinados instrumentos que ineludiblemente se convirtieron en reclamo inequívoco.

La calavera hizo de los fieles filósofos potenciales y de algunos santos -véase san Francisco en oración- Hamlets cristianizados. Pero la recomendación de los jesuítas lejos de ser novedosa, lo que hacía era recoger una tradición largamente asentada entre otras órdenes. Así, sabemos que los monjes capuchinos conservaban junto a sí los cráneos de sus hermanos muertos y a juzgar por los testimonios de la época podemos creer que fue un objeto de uso doméstico ${ }^{4}$.

Fruto de este ambiente fuertemente contemplativo y de una literatura espiritual especializada en el sentimiento de la muerte, las artes plásticas

Ver R. Curtius. Literatura europea y Edad Media latina, Madrid 1976, cap. X.

San Ignacio de Loyola. Ejercicios Espirituales. Madrid 1977.

Son noticias que nos aporta Fernando Martínez Gil. Muerte y sociedad en la España de los Austrias, Madrid 1993. En cuanto al uso de las imágenes, ya antes que los jesuitas, los dominicos y los franciscanos utilizaban y recomendaban estos usos en la meditación. Sólo por citar un ejem. plo, ver Francisco de Osuna. Segunda parte del libro llamado Abecedario espiritual, Sevilla 1530 , fol. XL. También santa Teresa las aconsejaba a sus monjas, aunque el mejor compendio de esta estampas de devoción fue el creado por el jesuita Jerónimo Nadal en sus Evangelicae Historiae Imagines, edición al cuidado de Alfonso Rodriguez G. de Ceballos, Barcelona 1979. 
se dejaron seducir por la corriente de estoicismo con la que se iniciaba la Edad Moderna y enseguida reflejaron la angustia ante la presencia de la muerte. Hay muchos especialistas que de manera magistral han evocado el sentido de la muerte en el Renacimiento y su repercusión en el arte ${ }^{5}$. Pero lo que ahora queremos analizar es uno de los apartados más ricos de la pintura española en los siglos XVI y XVII, el que corresponde a los santos penitentes quienes configuran, plásticamente hablando, una particular meditación de la muerte que oscila desde el ascetismo estoico a la melancolía cristiana amén de la sombra que la experiencia mística proyecta sobre este capítulo de la vivencia espiritual.

La aparición de los ermitaños en la pintura responde a lo que Jan Bialostocki define como tema-encuadre, aquel en torno al que se concentran unos contenidos tanto cristiano-religiosos como profanos y donde se vierte el pensamiento típico y especial de una determinada época ${ }^{6}$. En concreto, tras el apartado de los santos en meditación se vierten rnuchos aspectos a cada cual más complejo, ya que cada uno de ellos condensa el discurso espiritual, doctrinal y filosófico de la cultura de la España moderna.

El gran protagonista de la meditación fuen san Jerónimo no sólo porque es quien encabeza la nómina de santos penitentes que poblaron los lienzos renacentistas y barrocos sino porque fue él quien encarnó mejor que nadie la filosofia del menosprecio, de la renuncia a cualquier posesión terrenal. En sus Epístolas leemos aquello de que «quien siempre piensa que es mortal, lo desprecia todo con facilidad» y su leyenda hagiográfica rica y variada dió paso a una multitud de imágenes. La que prevalece fue la del santo anacoreta pero en su concepción pesarán las diversas circunstancias ideológicas y doctrinales que vivió la cristiandad en la que el cisma protestante y el Concilio de Trento radicalizarán las filas de la ortodoxia católica. Asi que en el discurso de la muerte y siendo san Jerónimo quien personifica la meditación, se vuelcan también las distintas concepciones religiosas y sin duda que su tratamiento iconográfico ha sido uno de

\footnotetext{
Citamos entre otros a A. Tenenti. El sentido de la muerte y del amor a la vida en el Renacimiento (Francia e Italia), Turín, 1977. A. Chastel. Le baroque et la mort. "Retorica e Barocco" (III Congreso Internazionale di Studi Umanistici) Roma, 1955. J. Bialostocki. Estilo e Iconografia. Contribución a una ciencia de las artes, Barcelona, 1977, en especial el capítulo «Arte y Vanitas".

6 Jan Bialostocki. op. cit. pág. 111 y sgs. Otros autores hablan de imágenes-tipo para definir estos modelos iconográficos que responden a una amplio apartado doctrinal y teórico. Ver Fernando Checa, Pintura y escuitura del Renacimiento en España, 1450-1600, Madrid 1983. También a este respecto ver Palma Martínez-Burgos, "Imágenes-tipo y Modus orandi: las variantes iconográficas del santo en la pintura del Renacimiento español" Cuadernos de Arte e Iconografía, F.U.E. tomo II, n. ${ }^{\circ} 4,1989$, págs. 30-35.
} 
los que más se ha transformado adaptándose a las necesidades del dogma católico frente a la Reforma protestante.

La fórmula que contó con más éxito fue la del santo haciendo penitencia en medio del paisaje. La búsqueda del retiro - siguiendo el ejemplo de los Padres del desierto-, guió a los pintores quienes le imaginan, sobre todo durante el siglo XVI, en medio de una naturaleza amplia y acogedora, un "locus amoenus" que a manera de Arcadia sugiere la idea de paraíso como contrapunto al pesimismo de la vida terrena. De este modo se articula una gran cantidad de imágenes en las que el mensaje es la reflexión sobre la soledad y el alejamiento de las vanidades mundanas, pero al incluir la penitencia y mortificación son también efigies que sugieren el deseo de seguir y rememorar la pasión de Cristo. En estas coordenadas se mueven dos pintores tan distanciados como Navarrete "el Mudo" y EI Greco. EL san Jerónimo del primero, todavía muy fiel a la composición de Durero, (fig. 1) se nos muestra en plena penitencia, no sólo la física sino la que implica la renuncia a la Arcadia, sugerida en el ameno paisaje del fondo. Menos narrativa y más dramática, la de El Greco (fig. 2) acusa los cambios sufridos en el seno del cristianismo y la radicalización de las ideologías enfrentadas. Prescinde de la naturaleza acogedora y opta por un encuadre rocoso, árido y duro, que subrraya y aísla la acción de autocastigo y del consiguiente desprecio, no ya de los bienes terrenales, sino de la propia carne. Como se ha señalado ya en otras ocasiones, san Jerónimo es el único de los penitentes que se maltrata y autocastiga como reconocimiento implícito del pecador, repitiendo así la agonía de Cristo pues al igual que $\mathrm{El}$, se golpea el pecho hasta sangrar evocando de este modo la herida del costado en la pasión cristológica?. A su lado el manto cardenalicio, el crucifijo y la calavera recrean el universo de la meditación y de la penitencia.

La confrontación de ambas imágenes evidencia que según nos adentramos en el debate religioso, el escenario de la meditación se irá modificando subrrayando los aspectos más polémicos. Frente a la justificación por la fe y la creencia en la predestinación, la Iglesia defiende el valor de la penitencia y el arrepentimiento de nuestros pecados. De este modo, muchos santos que no incluían en su leyenda la experiencia del eremitismo, se convierten, bajo este espíritu combativo en

Del paralelismo surge inevitablemente la alegoria del pelícano que los bestiarios interpretaron como símbolo del sacrificio de Jesús. Son algunas de las ideas contenidas en Isabelle DarvesBornoz. "Iconographie et Litterature: saint Jérôme et la peur de la mort au tournant du XVle. siècle, à Toledo" en A. Redondo (Dir). La peur de la mort en Espagne au Siècle D'Or. Litterature et iconographie, Paris, 1993, págs. 53-64. 


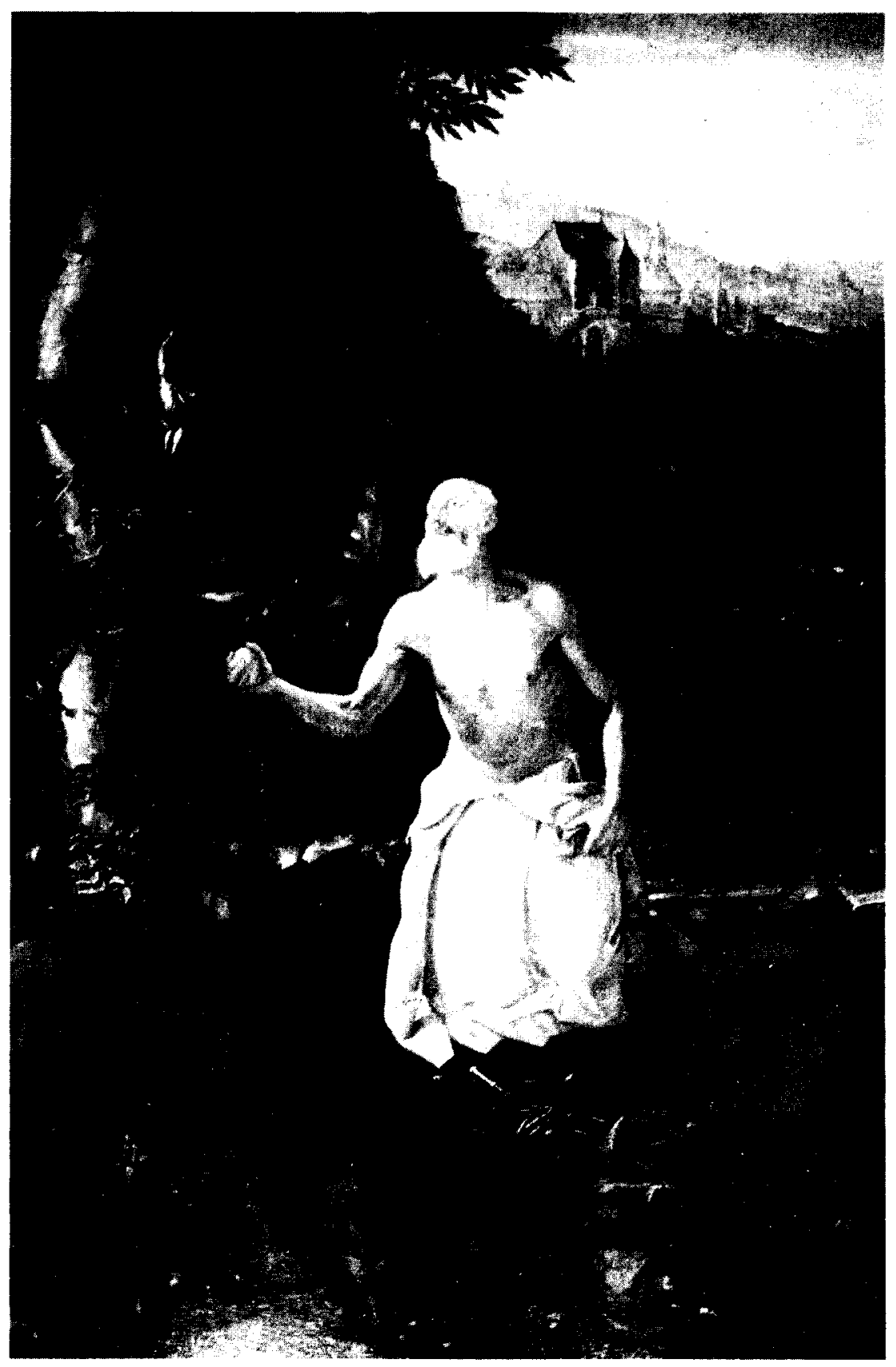

Fig. 1. J.F. Navarrete "EL MUDO». San Jerónimo, El Escorial. 


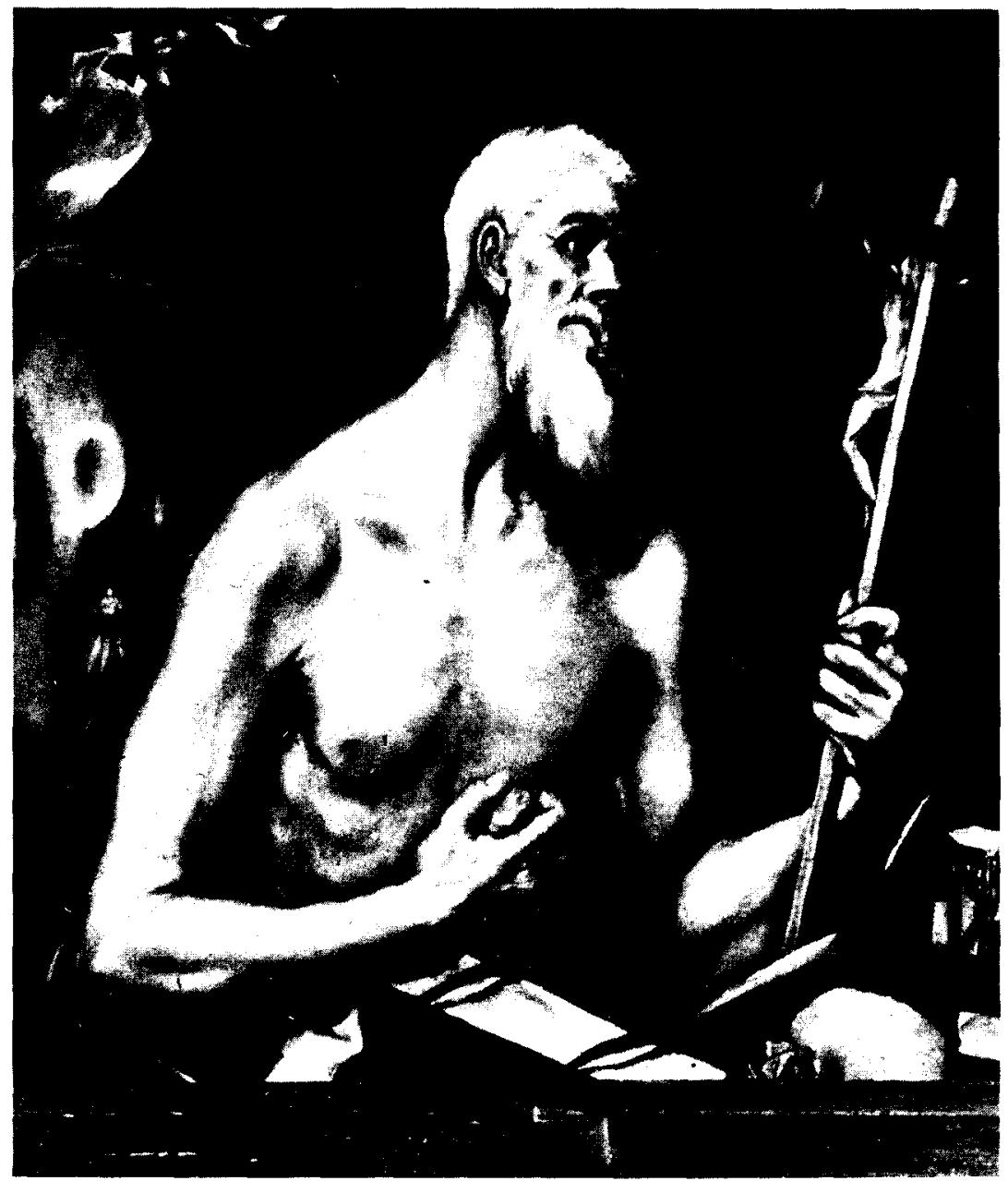

Fig. 2. EL GRECO. San Jerónimo penitente, Museo del Prado.

penitentes y ermitaños. Santo Domingo, san Francisco, san Pedro de Alcántara, las numerosas versiones de las lágrimas de san Pedro, santa María Egipcíaca, la Magdalena y un largo ecétera pasan a ser lección permanente del valor sacramental de la penitencia. ${ }^{8}$ El medio en el que se mueven, ya en el xvil también ha cambiado sustancial-

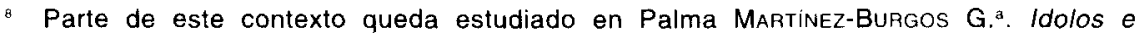
Imágenes. La controversia del arte religioso en el siglo xVI español, Valladolid 1990. De la misma autora ver «Ut pictura natura: la imagen plástica del santo ermitaño en la literatura espiritual del siglo Xvi" en Norba-Arte, Univ. de Extremadura, X, 1989. 
mente. El amplio paisaje ha dado paso a la cueva, a la celda oscura de la composición del lugar de los jesuitas. Luis Tristán sitúa a san Pedro de Alcántara (fig. 3) en medio de un espacio que tiene muchos puntos en

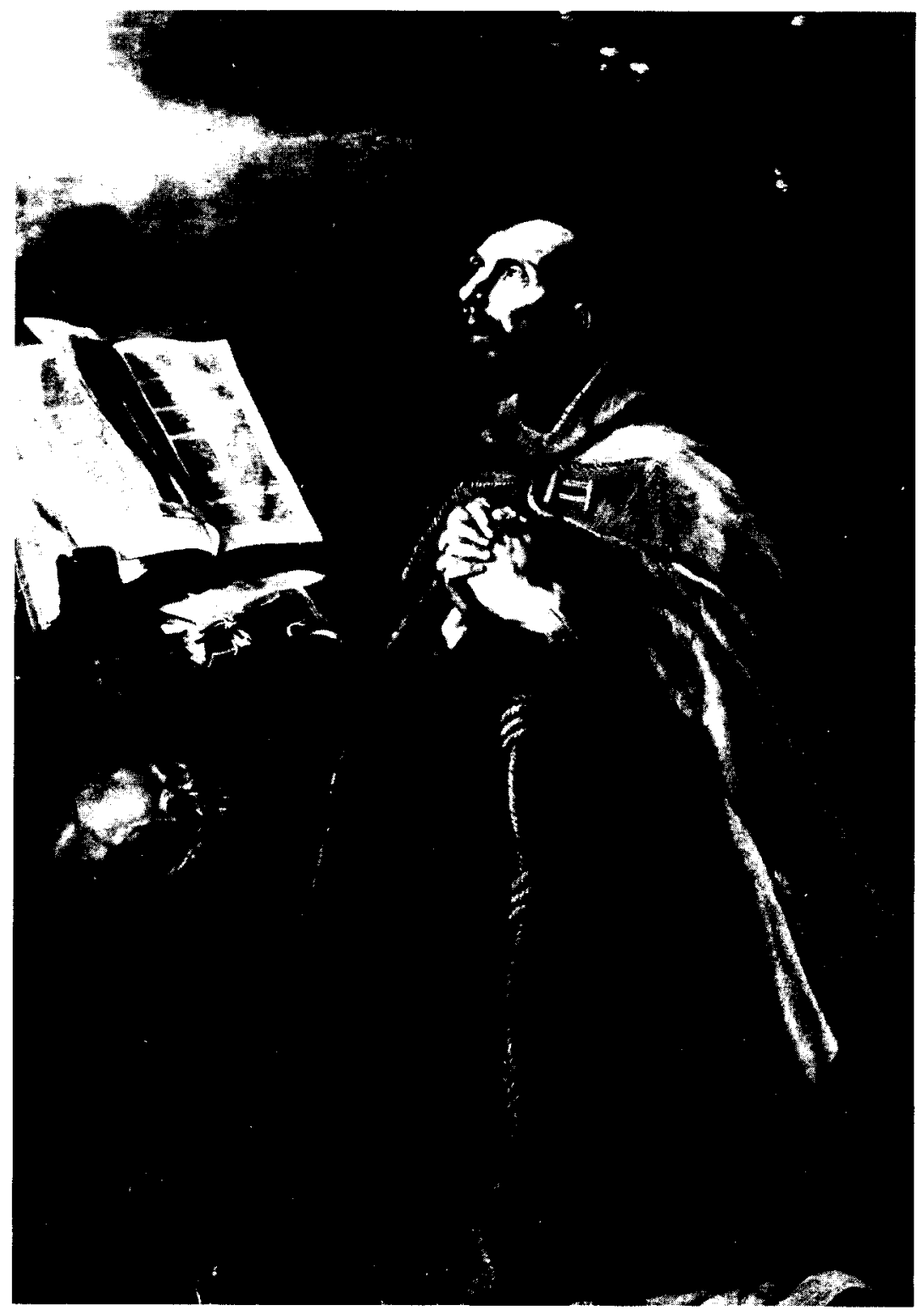

Fig. 3. L. TRISTAN. San Pedro de Alcántara, Museo del Prado. 
común con la mística de san Juan de la Cruz, donde el sujeto y el lugar son una sola realidad, ya que cuerpo y paisaje se integran en un fundido oscuro, metáfora de la inmensidad intima del alma, de la noche espiritual. El mismo paralelismo entre la roca y el cuerpo lo plantea Ribera en su san Pablo ermitaño (fig. 4). Descarnado, castigado y lúgubre, casi un muerto viviente, acusa el propio endurecimiento del ambiente religioso y la exaltación del sentimiento estoico frente a la muerte. Por tanto, nada tiene de extraño que nuestros penitentes mediten sobre la muerte aureolados de un ánimo de soledad y abandono que apunta hacia esa estética del desdén encuadrada por algunos especialistas dentro de la filosofía del desengaño que impregnó el espíritu de la cultura barroca ${ }^{9}$. Pero, en casi todas las imágenes propuestas el discurso acerca de la transitoriedad de nuestras vidas no sólo se ve en la calavera que acompaña indefectiblemente al ermitaño, también la vejez de los protagonistas

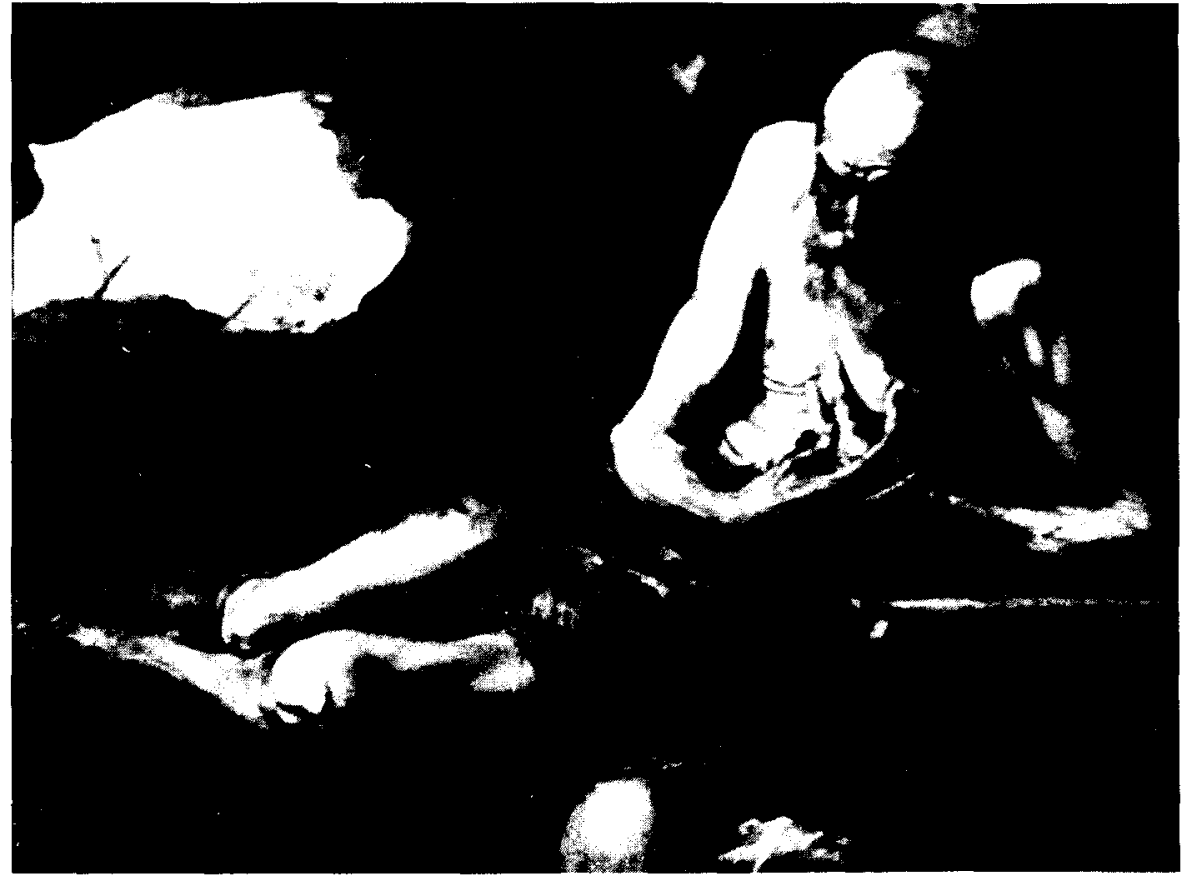

Fig. 4. RIBERA. San Pablo ermitaño, Museo del Prado.

9 Ver Alfonso Rodriguez G. DE CEBallos. "El sueño de la vida y el triunfo de la muerte en la iconografía del Barroco español" en Boletín de Arte, n. ${ }^{\circ}$ 13-14, 1992-93, págs. 7-25, Universidad de Málaga, Dpto. de H. ${ }^{a}$ del Arte. 
pasará a ser un elemento clave. Con ella se introduce la idea del Tiempo como un elemento más de reflexión, símbolo a partir del Renacimiento de la "vanitas" ya que la propia decadencia física forma parte del acatamiento de la muerte.

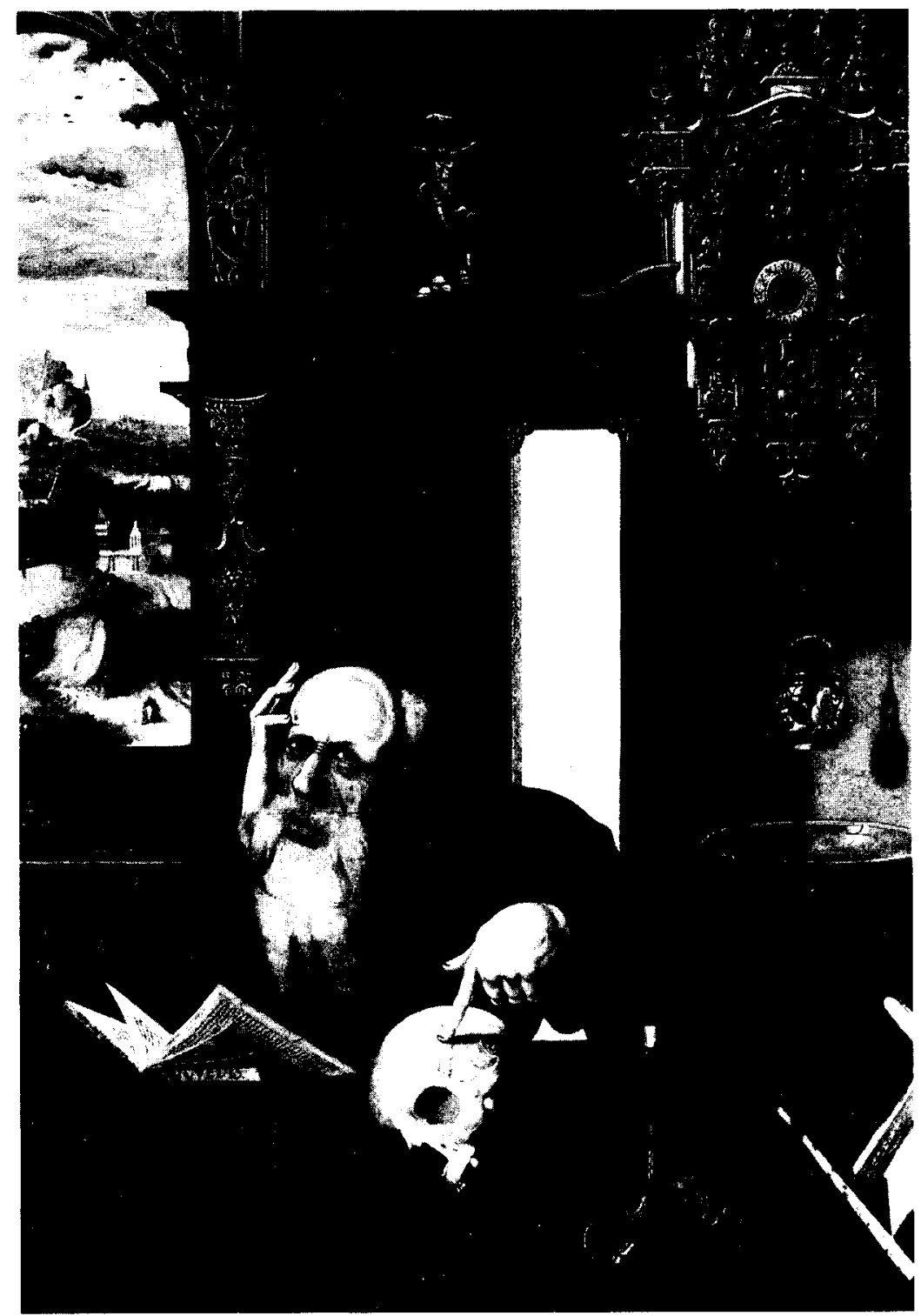

Fig. 5. JOOS VAN CLEVE (Taller). San Jerónimo en su estudio, Catedral de Burgos. 
En cambio, otras son las ideas que se vierten sobre las escenas en las que el santo aparece en su estudio. Demasiado culto para convertirse en una devoción popular, san Jerónimo se transmutó en el símbolo de los humanistas pues en él se resume la idea de una vida consagrada al estudio. Su faceta de traductor de la Biblia y autor de la Vulgata quedó tipificada en el grabado de Durero y en la tabla de Antonello de Mesina, en las que rodeado de los útiles de su trabajo intelectual recreaba interiores aptos para la demanda de los nobles y caballeros que, desde los inicios del siglo XVI, las destinaban a decorar sus despachos y estudiolos. La tabla de Marinus Reymerswaele en el Museo del Prado es una de las muchas que nos permite entender cómo en los Países Bajos el apacible y estudioso ambiente que respira la pintura de Messina se transforma en una tétrica lección. La obra de Marinus esta fuertemente endeudada con el san Jerónimo que pintara Quentin Metsys (Museo de Dusseldorf) y el que posee la catedral de Burgos procedente del taller de Joos van Cleve, (fig. 5). Son imágenes que siguen el modelo dado por Durero y que se conciben más que como la visión del santo humanista como una verdadera "vanitas". El reloj, la palmatoria con la vela apagada, el crucifijo, el libro abierto con la imagen del Juicio Final y, sobre todo, la fuerte gestualización sobre la calavera son los elementos que modifican radicalmente el significado del cuadro, y los que imponen la impronta de la caducidad de la vida.

Tal y como han señalado otros autores, ante el creciente capitalismo y consumo de objetos bellos que se despierta en la civilización renacentista, la Iglesia insistía en que las riquezas acumuladas eran una pura nada ${ }^{10}$. En paralelo, el rigorismo protestante predicaba una ética aún más radical, por lo que no debe sorprender que sea en la opulente sociedad burguesa septentrional en la que aparezcan estos motivos. Pero es que además traduce la concepción flamenca y holandesa de analizar detalladamente el carácter perecedero de la naturalea y del mundo a través de la suntuosidad de las cosas visibles. De entre ellos, destaca el formidable reloj mecánico que ha sustituído al de arena, más habitual en este tipo de composiciones, y que siempre recuerda la transitoriedad de nuestras vidas ". Pero el reloj va a ser también enseña del orden del sabio, alusión al tiempo domesticado e interiorizado además de referencia a la virtud de la paciencia

Esta actitud ante la caducidad de la vida era compartida por los humanistas por lo que si es posible mantener la dualidad propuesta en esta imagen de santo estudioso y, a la vez, ejemplo de "vanitas". Cfr. J. HALE. La civilización del Renacimiento en Europa, 1450-1600. Barcelona 1996.

Sobre el simbolismo que encierran estos atributos hay una amplia bibliografia. Cfr. JAN Bialostocki. op cit. pág. 197. Para el ámbito de la pintura española J. GálLEgo. Visión y símbolos de la pintura española del Siglo de Oro, Madrid 1972, y R. MARTIN. Barroco, Madrid 1986. 
propia del temperamento de los humanistas y estudiosos. Junto a él, los instrumentos de escritura y las gafas en el primer término siguen siendo objetos propios del intelectual y del microcosmos en el que medita. Y asi a los atributos intrínsecos de la sabiduría - libros, gafas, pluma- se les añade el símbolo del final de todas las cosas. La calavera entre dedos como garras descarnadas o bajo el dedo retórico y conductor es la que cataliza la reflexión del sabio. Pero además de ser el objeto privilegiado para crear el sentido del "memento mori», la aparición del cráneo responde al interés científico que la pintura comienza a sentir. Chastel enunció que su reiterada introducción entre los objetos de meditación no tiene sólo un significado religioso, sino también científico ya que responde al mayor conocimiento anatómico con el que los pintores ayudaban a ilustrar las primeras representaciones anatómico-científicas. Cierto que, siguiendo al crítico francés, estas incursiones de la pintura mantenian todavía un carácter alegórico por lo que las denomina «anatomías moralizadas" ${ }^{12}$. Fue el deseo de mostrar un buen manejo de la anatomía lo que llevó a los pintores, especialmente a los flamencos, a mostrar la calavera bajo un complejo juego de escorzos y perpectivas como se puede contemplar en la que incluye Marinus en la tabla del Museo del Prado (fig. 6).

La certeza de estar meditando sobre la vanidad del mundo, de ser el observador privilegiado de la caducidad y de lo efímero, invade la atmósfera de una sutil pesadumbre y tristeza, de modo que no sorprende el aire «saturnal» que envuelve las imágenes del santo estudioso. La tabla de Joos van Cleve insiste además en la propia postura de la figura que reclina meditabundo la cabeza sobre la mano y que en opinión de los especialistas es la actitud que define por antonomasia el espíritu melancólico ${ }^{13}$. No es de extrañar si tenemos en cuenta que el "homo melancholicus" es aquel que ha optado preferentemente por la vida contemplativa y estudiosa y que es precisamente la mente contemplativa la que lleva aparejada el estado melancólico. "Son muchos los hombres santos y piadosos que se vuelven melancólicos por su gran piedad y por temor a la ira de Dios o debido a su gran anhelo de Dios

\footnotetext{
Chastel denomina "anatomias moralizadas" a aquellas en las que la descripción minuciosa de la anatomia se acompaña de gestos y movimientos que expresan un sentimiento particular sobre el destino del hombre. Las contrapone a las "anatomias sensibles". A. CHASTEL. Op. cit. pág. 43 y sgs. A este respecto es interesante la relación entre los emblemas y los temas de "vanidades" planteada por J.M. Monterfoso Montero. "La Dulce Vida de la Muerte. Breve visión emblemática de la existencia" en el Cat.-Expo. Speculum Humanae Vitae. Imagen de la Muerte en los inicios de la Europa Moderna, La Coruña, 1997.

is. Klibansky, E. Panofsky y F. SAxl. Saturno y la melancolía, Madrid, 1991, págs. 307 y sgs. Señalan entre los motivos asociados a Saturno, la cabeza apoyada en la mano, la bolsa y las llaves, el puño cerrado y el rostro sombrio y cetrino.
} 


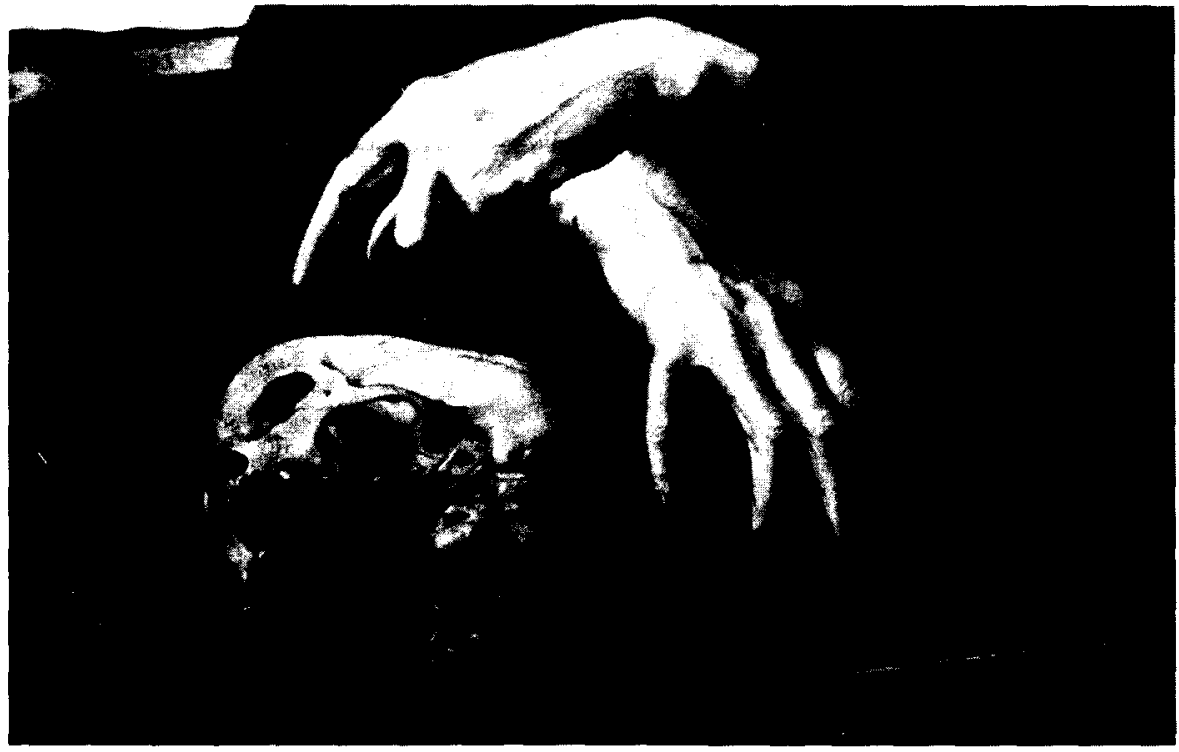

Fig. 6. M. REYMERSWAELE. San Jerónimo, Museo del Prado.

que acaba por señorearse del alma y aplastarla... Caen en la melancolía todos los que se esfuerzan en la lectura de libros filosóficos... "14. Y es evidente que el ascetismo exagerado condujo al estado saturnal. Ese es al menos el espíritu que hemos podido rastrear en muchas de las escenas sobre san Jerónimo. Chastel personificó en san Antonio abad el espíritu de la melancolia por sus estados alternativos de crisis y contemplación serena, sin embargo a partir de 1450 aproximadamente fue san Jerónimo quien recibe el testigo y encarna al tipo melancólico, sobre todo a partir del momento en el que la meditación de la muerte se libera de la necesidad de una identificación y en el que la figura del santo se convierte en la síntesis del saber humano a modo de espejo que refleja la estructura moralizada del mundo ${ }^{15}$. Un magnífico ejemplo es el que ofrece el san Jerónimo de J. Bassano custodiado en la Galería de la Academia de Venecia (fig. 7). La gruta ha pasado a ser el estudio del santo y desperdigados aparecen ante nuestros ojos los objetos del sabio, los libros y la clepsidra se mezclan con los instrumentos de la santidad,

${ }_{14}$ Seguimos las disertaciones de Constantino Africano en Opera, vol. I, págs. 291 y sgs. recogidas por Kiblansky, Panofsky y Saxl. op. cit. pág. 102.

${ }_{15}$ A. Chastel. "La tentation de saint Antoine ou le songe du melancolique" en Gazette des Beaux-Arts, vol. LXXVII, 1936, págs. 218 y ss. También el estudio de D. Russo. Saint Jerôme en Italie. Etude d'iconographie et de spiritualité. XIII XVI siècles, París, 1987. 


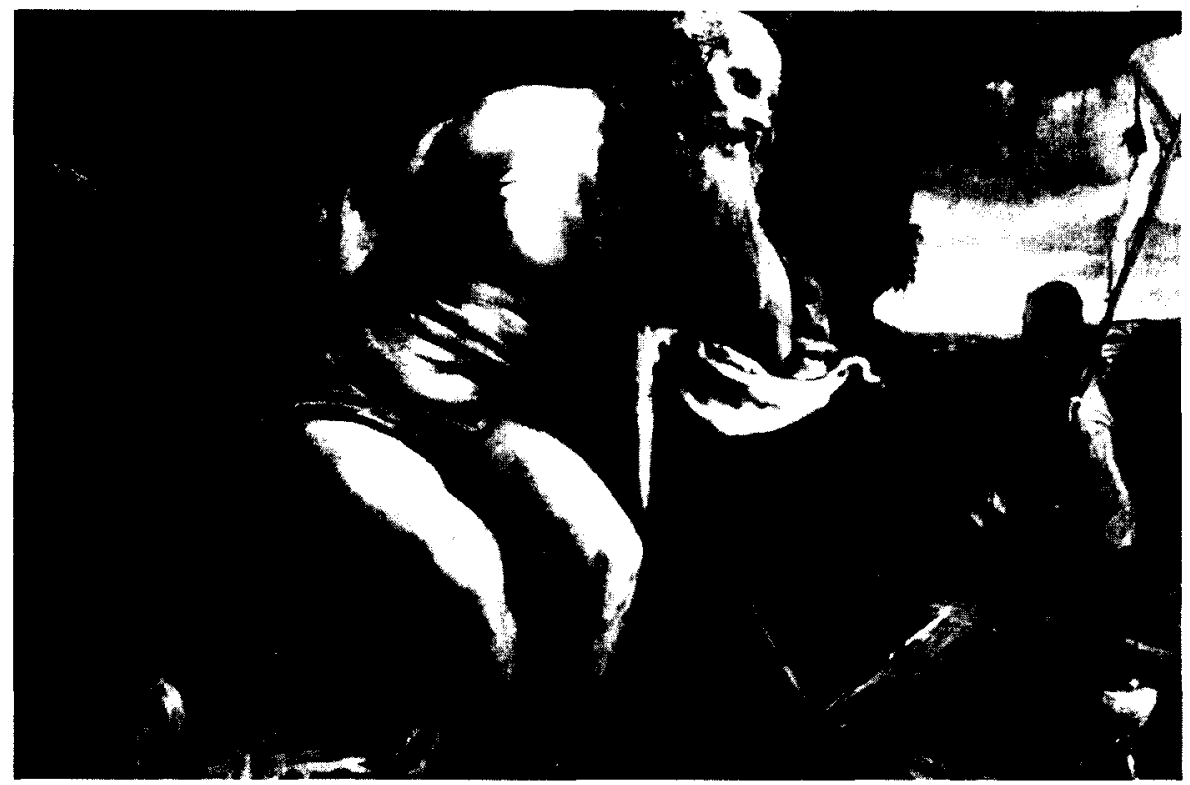

Fig. 7. J. BASSANO. San Jerónimo, Galería de la Academia. Venecia.

el crucifijo, la calavera y la piedra ensangrentada que esconde la mano derecha, mientras que la izquierda sostiene la cabeza barbada haciendo de la imagen contemplada un verdadero «memento mori». La misma intención subyace en el dibujo de Antonio de Pereda para su santo (fig. 8) y en el de Diego Polo del Museo del Prado, amén de tantos otros. La tentación de san Jerónimo es la melancolía, la misma que invade a María Magdalena. Salvo las imágenes iniciales pertenecientes al siglo xVI, —véase el Anónimo de la figura 9 en la que la santa, todavía un tanto pizpireta, reclina la cabeza al tiempo que medita acerca de la salvación-, las que produjo la pintura de la centuria siguiente son en ocasiones verdaderos ejemplos de la ambigüedad que invade este tipo de figuraciones. Cualquiera de las muchas Magdalenas de Ribera que alberga la Pinacoteca madrileña (fig. 10) transcribe la tristeza cristiana que genera el arrepentimiento de los pecados y conduce a la salvación, según la Epístola de san Pablo a los Corintios $(7,10)$, distinta a la tristeza del mundo que sólo engendra la muerte. Dicen los autores del estudio sobre Sarturno y la Melancolía que sólo cuando la meditación de la muerte se liberó de una personificación concreta «... se fue acentuando cada vez más el contraste fascinante entre el contenido horrible de la meditación y la belleza juvenil del sujeto que medita, con lo que san Jerónimo vino a ser sustituído frecuentemente por una Magdalena» y a decir verdad que la de Ribera poco dista de "La Meditación" que aparece representada en el lienzo de 


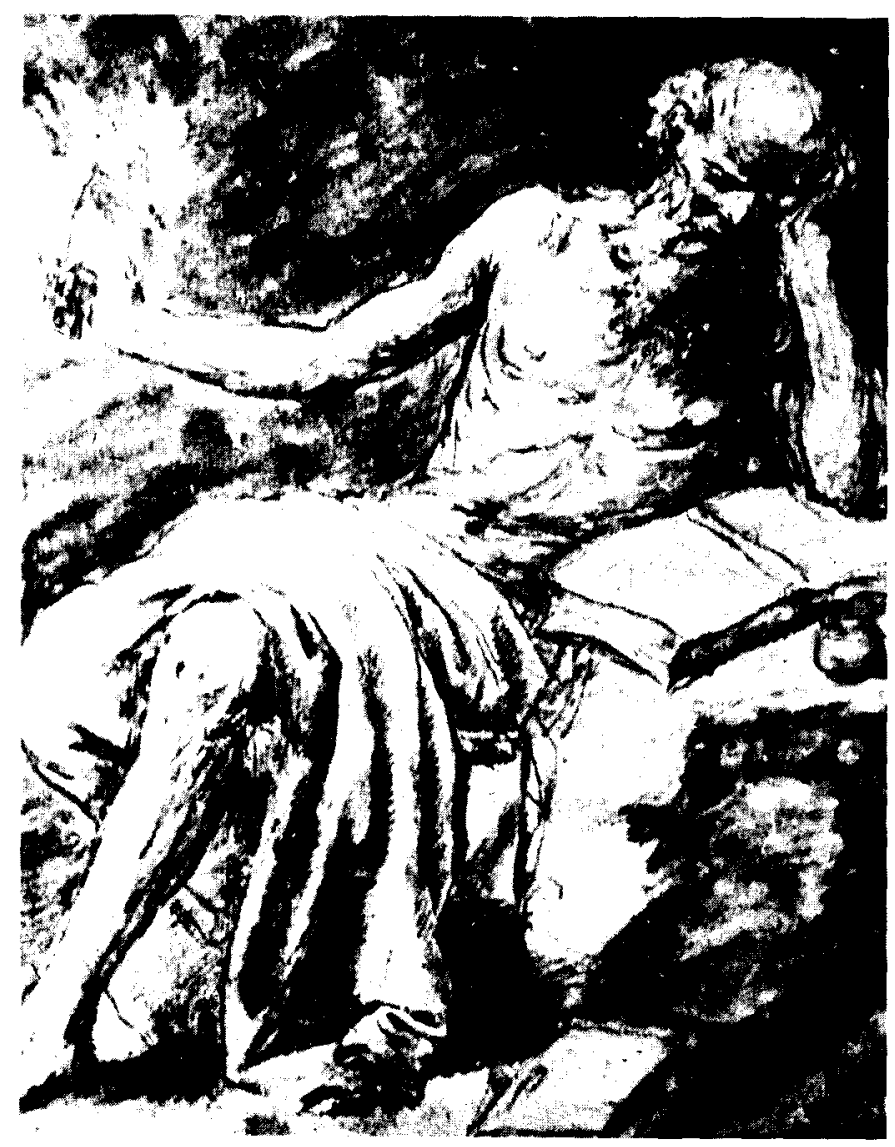

Fig. 8. A. DE PEREDA. San Jerónimo, British Museum. Londres.

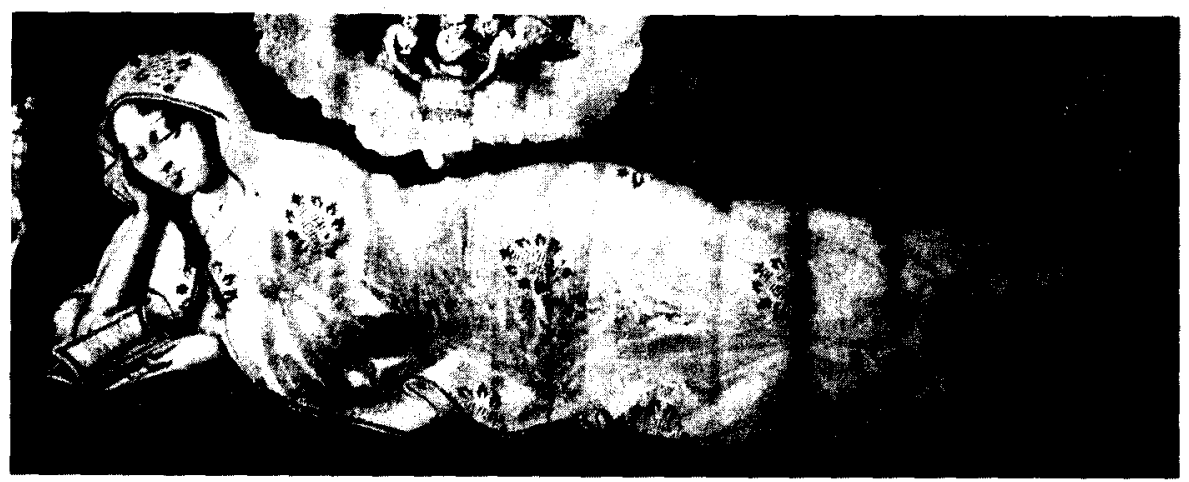

Fig. 9. ANONIMO. Magdalena penitente, Convento de santo Domingo el Real. Toledo. 


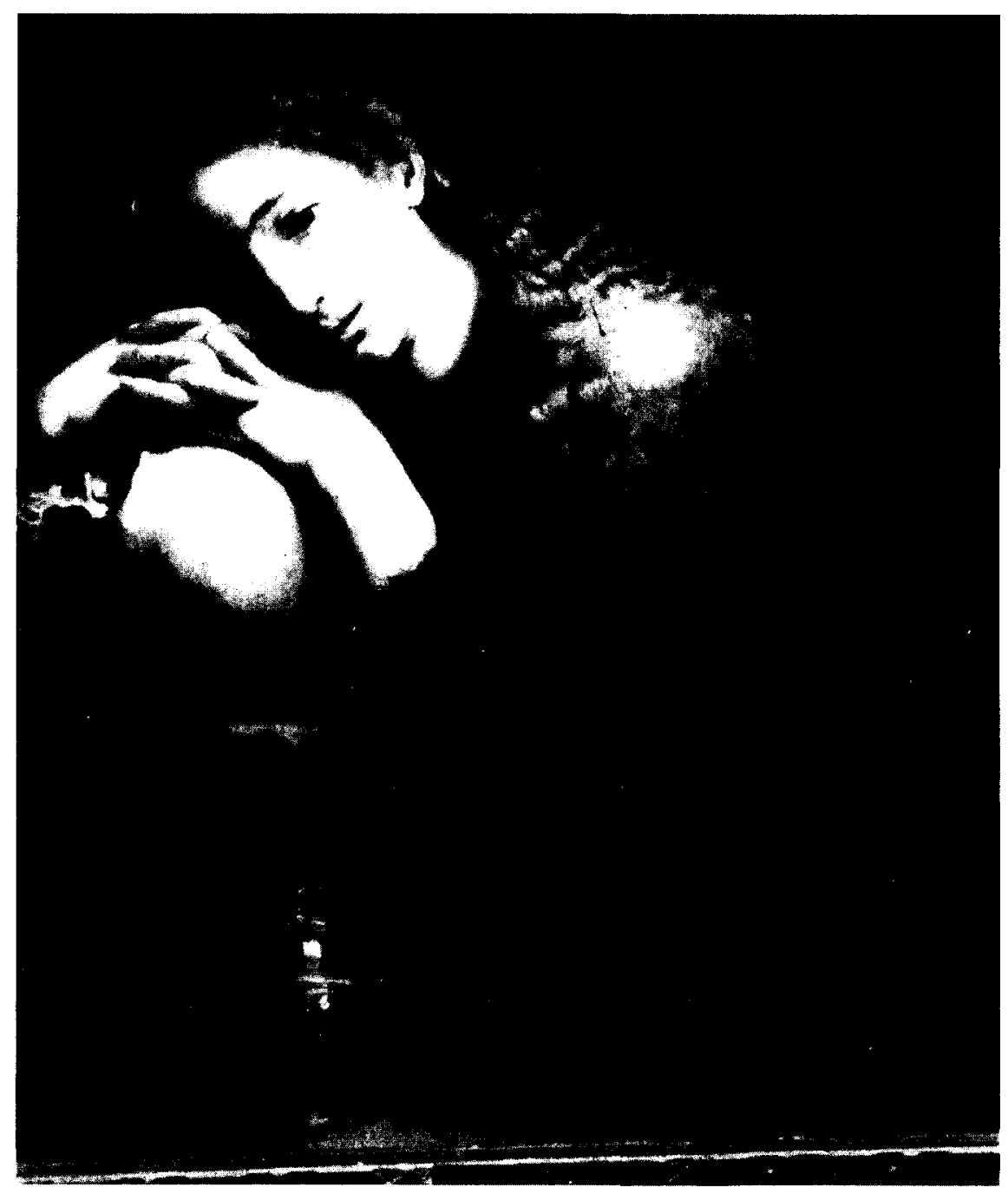

Fig. 10. RIBERA. La Magdalena, Museo del Prado. 
Domenico Fetti de la Academia veneciana (fig. 11) con lo que la afirmación de que "ahora la Melancolía se asemeja al tipo de la Magdalena arrepentida" se hace más acertada que nunca ${ }^{16}$.

De alguna manera en ellos, en todos los penitentes que poblaron nuestra pintura y especialmente en $\mathrm{M}^{\text {a }}$ Magdalena, se da la exaltación de la belleza ausente, la renuncia a todo lo terrenal salvo al propio conocimiento. Por eso junto a la calavera que todos sostienen hay un libro inexorablemente abierto. De hecho, sabemos que entre los muchos «instrumentos de ermitaño" que caracteriza la profesionalización de anacoretas, los libros formaban un capítulo importante.

Entre el "ora et labora" en el que discurre su existencia se les recomienda la dedicación «sin tasa ni término a la oración mental pues es este el principal ejercicio del solitario..." " so dificultoso se aconseja la ayuda de algún varón espiritual y la lectura de libros devotos de los que podemos señalar el Libro de la oración y meditación de Fray Luis de Granada, la Summa de fray Pedro de Alcántara y el Arte de servir a Dios de fray Alonso de Madrid ${ }^{18}$. Es decir, se trata en su mayoría de obras de meditación y ejercicios espirituales que en gran medida giran en torno al tema de la Pasión y muerte de Cristo, argumento central de la predicación contrarreformista. Si leemos detenidamente este tipo de relatos o los propios sermones sobre la pasión, lo primero que advertimos es el carácter sombrio y desgarrador que se vierte sobre este pasajo. Aunque nunca la pintura recoge el dramatismo que sí tiene la palabra, oral y escrita, lo cierto es que los artistas sí se dejaron sugestionar por esa obsesión omnipresente de la muerte y la automortificación. La propia ortodoxia católica recomendaba el uso de la disciplina por su bondad medicinal y vindicativa ${ }^{19}$. Y como decíamos al inicio de estas páginas,

\footnotetext{
El paralelismo queda magistraimente establecido en Kiblansky, Panofsky y Saxl. op. cit. págs. 366-369. Por otra parte el discurso médico de la época atribuía una mayor propensión de la mujer al estado melancólico en virtud de la teoría de los humoies y las versiones moralizadas de los temperamentos. La propia teología medieval interpretaba la melancolía como ula pena de Adán". Para una mayor información acerca de la melancolía y el éxtasis religioso en la iconografia de las santas véase $P$. MARTinez-BuRgos $G$. ${ }^{a}$. "Los sueños de Eva: visiones, éxtasis y raptos en la sensibilidad del Barroco" en B.S.A.A. n. ${ }^{\circ}$ 53, 1997.

17 Constituciones de ermitaños de Navarra de 1590, en Palma Martínez-Burgos. Idolos e Imágenes, op. cit.

18 Son datos que aporta Gabriel Llompart. "Lecturas de ermitaños mallorquines", Studia Monástica, 1976, vol. XXXVIII, págs. 119-130.

${ }_{19}$ Medicinal, porque fortalece el cuerpo y vindicativo porque ayuda a purgar los pecados. $\mathrm{Cfr}$. G. Llompart. "Desfile iconográfico de penitentes españoles, (ss. XVI-XX)" en Revista de Dialectología y Tradiciones, Madrid 1969, tomo XXV.

Ver tambien Palma Martínez-Burgos G. ${ }^{a}$. "Ut pictura natura...", op. cit.
} 
PALMA MARTÍNEZ-BURGOS G. ${ }^{a}$

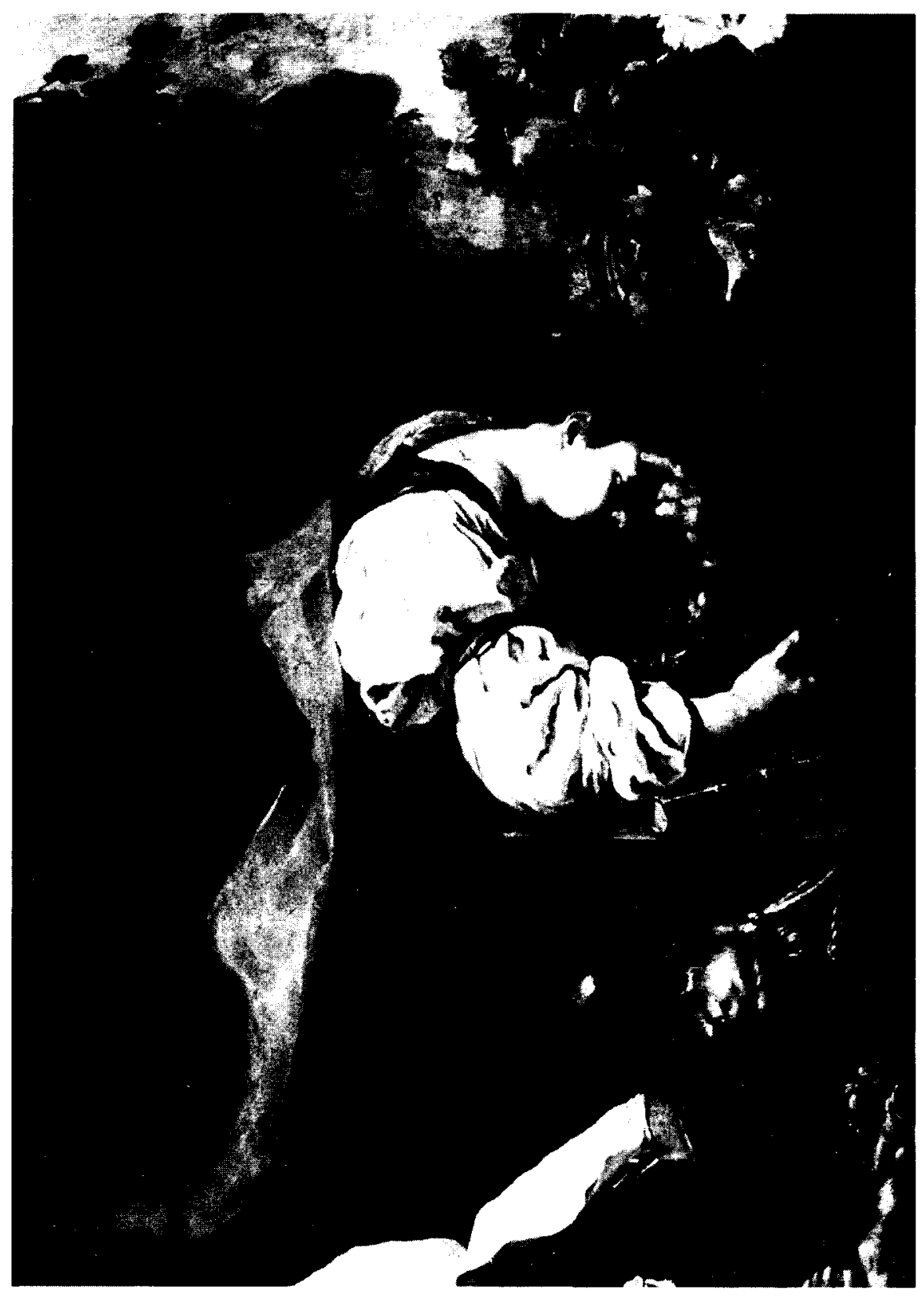

Fig. 11. D. FETTI. La Meditación, Galeria de la Academia. Venecia. 
dentro de este panorama de exaltación de la mortificación, surgieron por doquier las llamadas cofradías de fragelantes que tenían por objeto golpearse hasta hacerse sangre imitando, a veces peligrosamente, lo que predicadores y escritores decían que había sido la Pasión de Cristo ${ }^{20}$. No obstante y especialmente en este apartado iconográfico hay siempre una alusión a la Biblia Vulgata de la que San Jerónimo fue autor y que se convirtió a raíz del Concilio de Trento en la versión oficial de la Iglesia. De ella uno de los textos objeto de reflexión es el Apocalipsis y así, las referencias explícitas al día del Juicio final se hallan en algunas de las escenas de nuestra pintura. Luis Tristan (fig. 12) concibe una peculiar personificación en la que condensa todas las ideas vertidas en la meditación de la muerte protagonizada por los penitentes. Opta por la versión del humanista encerrado en su celda, - este detalle es ya significativo y tardío para una época que prefiere la gruta-, con lo que funciona a manera de retrato de hombres ilustres. Con ello destaca la importancia del hombre de estudio, individualista y seguidor de la recta conciencia que proclamara el pensamiento de Erasmo de Rotterdam. Símbolo de la sabiduria, el santo vuelve a expresar con el gesto de la pierna cruzada la nostalgia del momento final que le anuncia la llamada de la trompeta. En cambio Alonso Cano (fig. 13) envía un angel trompetero para recordar el juicio del alma, abriéndose paso en medio de la gruta que adquiere función de sepulcro, el mismo que por espacio de tres días albergó el cuerpo de Cristo afianzándose de este modo el sentido funerario que encierra la escena.

Ascetas y melancólicos sirvieron de laboratorio espiritual ya que en torno a este complejo apartado iconográfico del eremitismo se debatió otro de los puntos doctrinales conflictivos de la ortodoxia católica, el del «locus orandi". Para la férrea disciplina católica el único espacio apto para la oración era el que brindaba el templo con la plegaria tutelada y colectiva. Sin embargo no pudo desterrar las posturas individualizadas que apostaban por el retiro solitario y la oración mental. La Iglesia receló de los ejemplos de santa Teresa quien buscaba los lugares apartados, o de san Juan de la Cruz con su revalorización del mundo circundante. Poco a poco y a través de las imágenes pictóricas, se formula una sacralización de la naturaleza que alcanza su mejor expresión teórica en las palabras del beato Alfonso de Orozco:

\footnotetext{
20 «...cuerpo de cardenales, rasgarse los huesos, reventar la sangre y correr a hilo por todas partes, descubriendo los huesos blancos entre la carne colorada...", asi narra fray Luis de Granada la "Meditación tercera sobre los pasos del texto de los Evangelistas" en el Tratado de la oración y meditación, Barcelona 1767.
} 
PALMA MARTÍNEZ-BURGOS G. $^{\text {a }}$

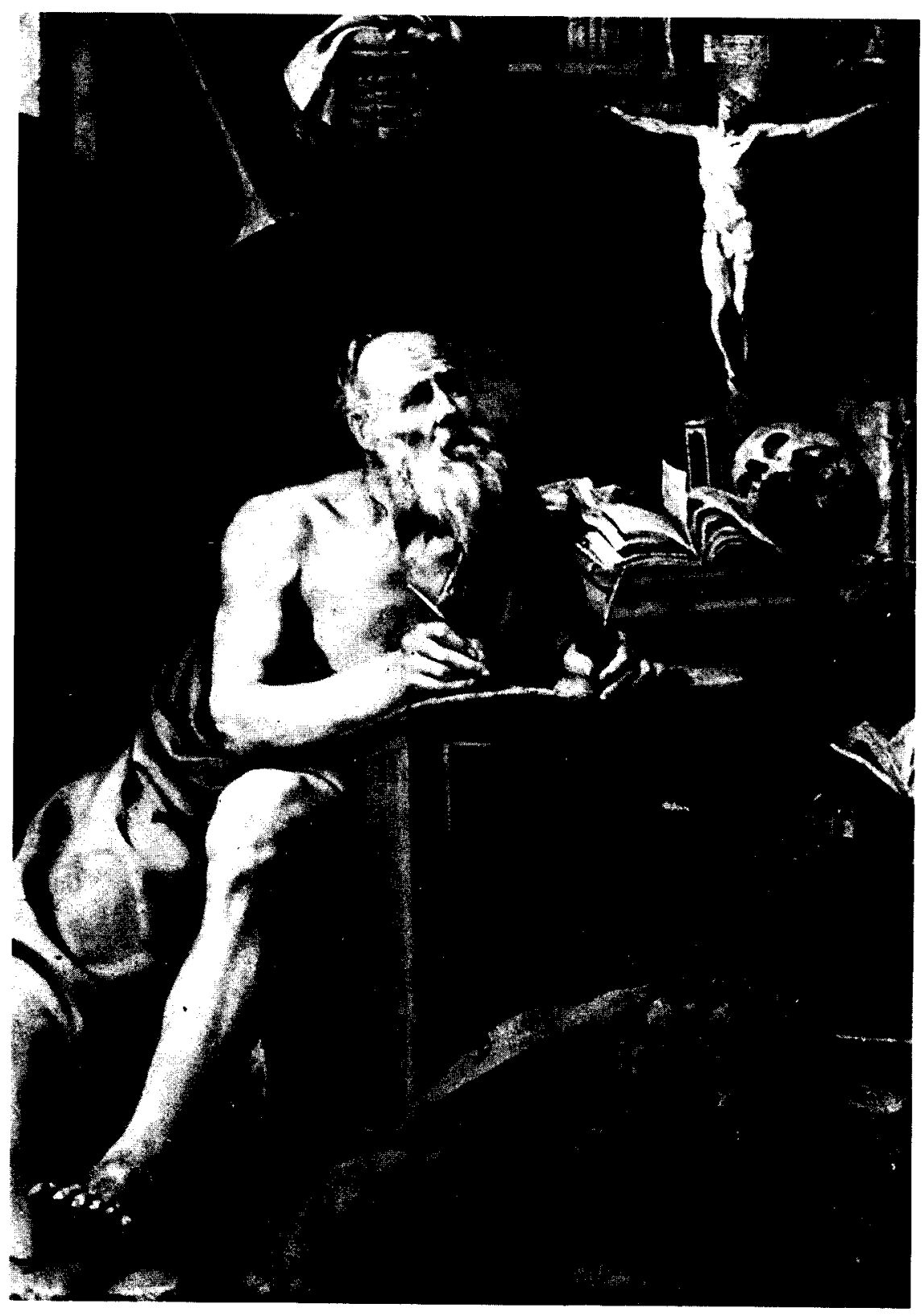

Fig. 12. L. TRISTAN. San Jerónimo, Convento de san Pablo. Toledo. 


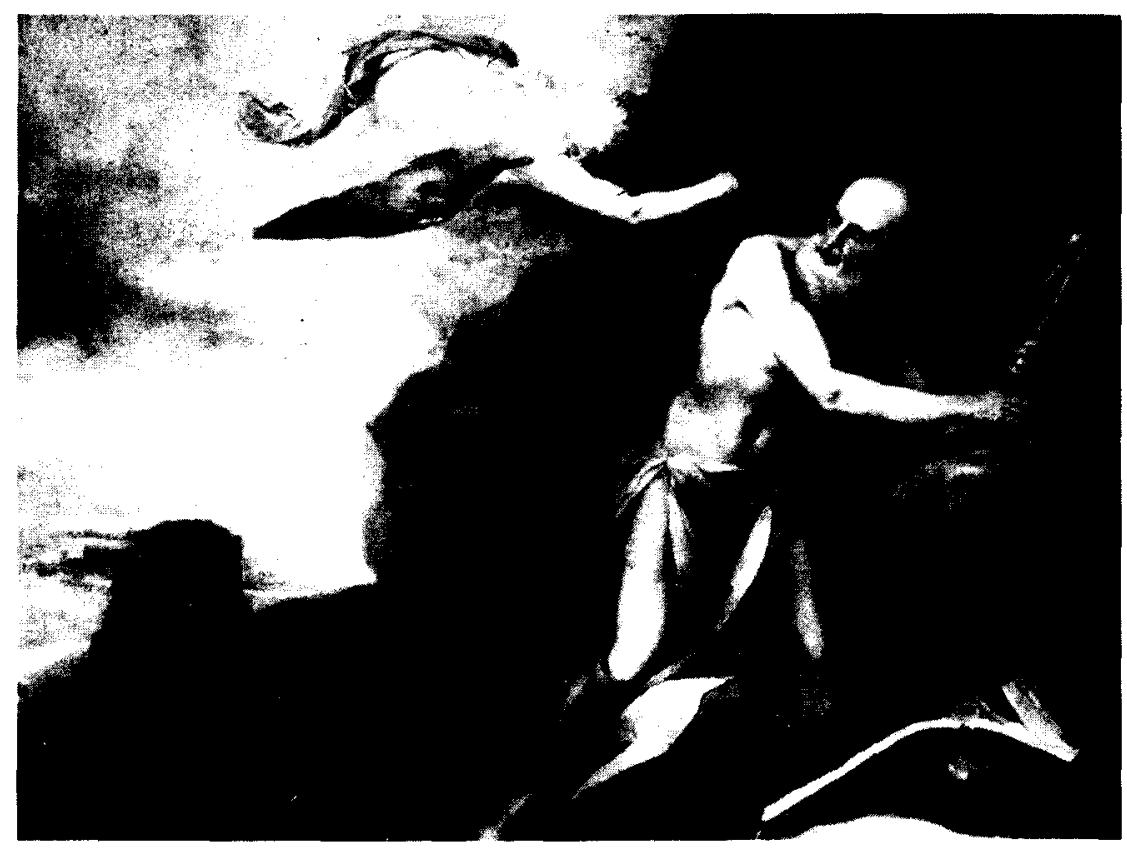

Fig. 13. A. CANO. San Jerónimo, Museo del Prado.

«El remedio es, según Christo nuestro redemptor, quenos ascondamos para orar... Para eso quiso nuestro Salvador salir al campo y hacer oración a solas..." ${ }^{21}$.

La oposición de santa Teresa a los edificios suntuosos - «Oh! Válgame Dios! que poco hacen estos edificios y regalos exteriores para lo interior..." escribe a propósito de la fundación de uno de sus conventosy la corriente cada vez más generalizada de una nueva concepción de la religiosidad permitió la materialización de un nuevo "locus orandi» que a pesar de las críticas, cristalizó tanto en la pintura como en la literatura donde abundan los títulos con metáforas paisajistas, a la manera de "vergel de oración», «jardín de amores santos», "monte de contemplación» y un sínfín de ellos que sería prolijo ennumerar ahora ${ }^{22}$. Lo cierto es que la

21 AlFONSO DE OROzCO. Vergel de oración y monte de contemplación, Sevilla 1548, cap. V, fol. LIII.

22 En efecto, los citados responden a fray Bernardino de Laredo. Subid. del Monte Sión, Alcalá 1578. Fray Francisco Ortiz Lucio. Jardín de amores santos, 1558 y san P. drn de Alcántara. Vergel espiritual del alma religiosa, 1610.

En cuanto al pensamiento teresiano arriba consignado queda recogido a. canta Teresa de Jesús. Las Fundaciones en Obras Completas, Madrid 1954. 
iconografía de los penitentes condensó magníficamente esa esencialidad de la celda carmelitana resumida en luz, espacio vacío y algún objeto humilde. De ahí la belleza ausente a la que antes nos referíamos, la belleza y la fuerza expresiva de lo que no aparece.

Hasta ahora y ante el complejo panorama en el que se desenvuelve la pintura de santos en meditación, los sentimientos barajados apuntan hacia el desprecio del mundo, el ansia de la soledad y la lección permanente que nos da la certeza de la muerte bien sea a través de la meditación estoica, bien a través de la sabiduría melancólica. Pero a las dos opciones ya conocidas podemos añadirle una más, la meditación mistica que toma cuerpo en los propios manuales de oración para dejar luego su impronta en la pintura. Hasta los pedagogos cristianos más prudentes hubieron de asumir que el éxtasis o cualquier otro arrebato místico, podía llegar tras una intensa jornada de plegaria. Juan Lorenzo Palmireno, el humanista aragonés autor de numerosos libros morales y manuales devotos afirma que «Assi que después de la oración devota, viene la contemplación; con la cual entrando nuestro pensamiento en la casa real del omnipotente Dios, viene en extasi arrobado en la Magestad de gloria, potencia, sapiencia, eternidad del inmenso en las alturas...", en el mismo discurso dice más adelante que si "en medio del rezar sientes que tu anima se levanta y suspende en algún gran affeto y sentimiento de amor o temor de Dios, y admiración de sus obras, dexa las palabras, y goza del sentimiento que el Espíritu sancto te da» ${ }^{23}$.

Semejante pensamiento lo hallamos en otros autores y no sorprende por lo tanto que la pintura acusara pronto esta faceta tan atractiva y que tantos retos suponía a la hora de llevarla al lienzo. Con los visionarios nos adentramos en los terrenos sobrenaturales de los éxtasis, sueños y raptos, tan queridos de la espiritualidad más exaltada del Barroco y tan temidos

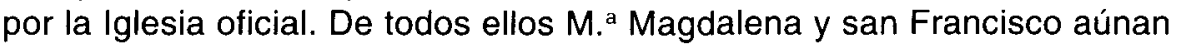
la meditación de la muerte con el éxtasis místico por lo que van a ser los dos grandes protagonistas de este apartado. De la primera sólo cabe insistir, a estas alturas, en el encanto que ejerce dentro de una nómina de penitentes mayoritariamente masculina. Ella es la gran protagonista femenina de la renuncia y la mortificación y a decir de su hagiografía gozó de los dones sobrenaturales ya que «Estuvo por treinta años en soledad, comiendo yervas y rayzes de árboles, gastáronse los vestidos y vistióla Dios

${ }^{23}$ Juan Lorenzo Palmireno. Camino de la Iglesia pág. 73 y sgs. Citado y desarrollado por A. Gallego Barnes Juan Lorenzo Palmireno (1524-1579). Un humanista aragonés en el Studi General de Valencia, Zaragoza, 1982. 
con sus cabellos, siendo levantada entre día y noche por los angeles..." nos cuenta uno de sus hagiógrafos ${ }^{24}$. Muchos fueron los pintores que escogieron esta faceta espiritual de la santa, entre ellos algunas de las de Ribera o la impresionante Magdalena de J.J Espinosa del Museo de san Pío $V$ de Valencia en la que se aúna toda la fuerza de la "morbidezza» y del gesto que acompaña el favor divino.

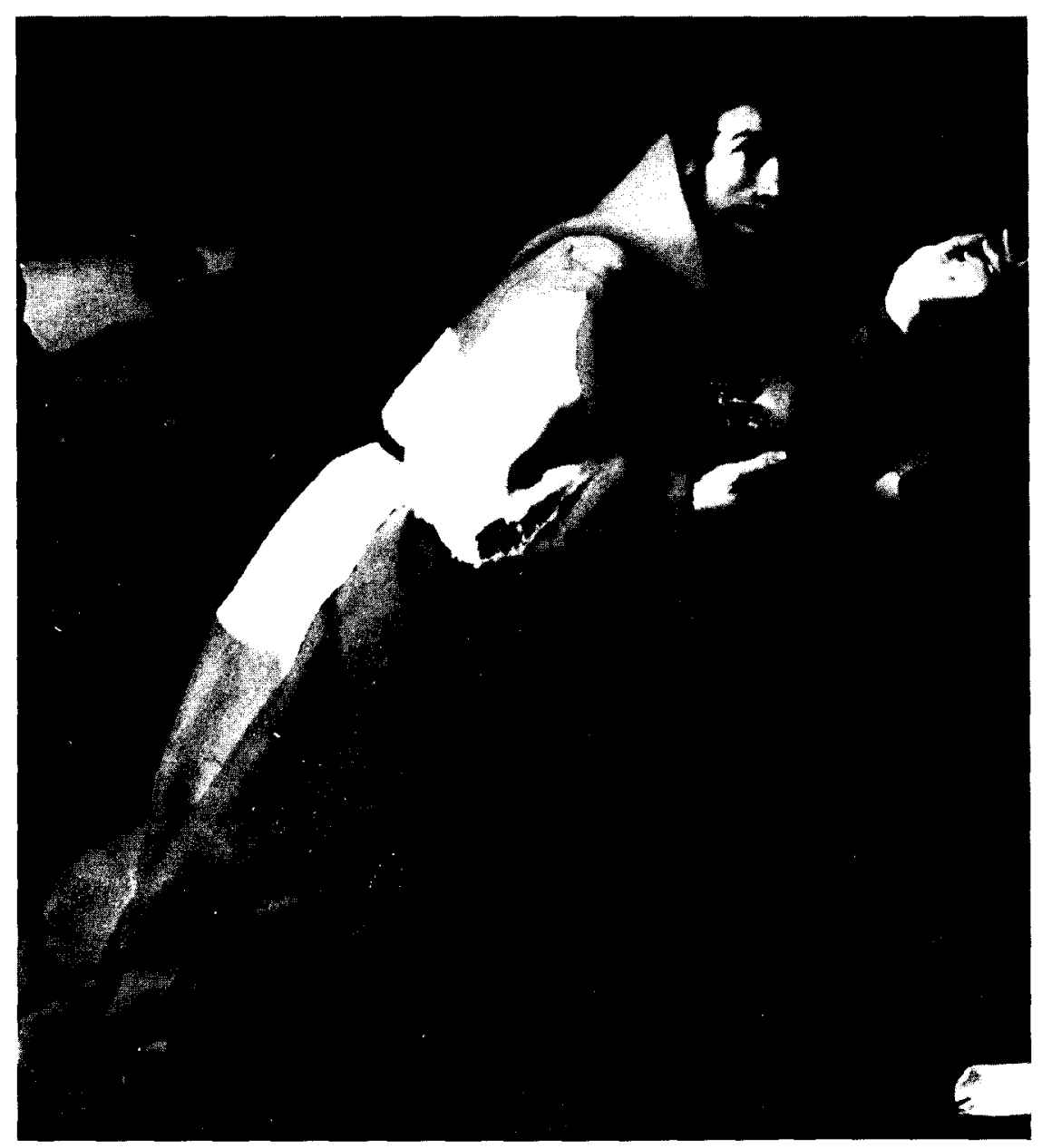

Fig. 14. ZURBARAN. San Francisco en meditación, National Gallery. Londres.

24 En este caso se trata de fray Diego de Coria. Dilucidario idemostracion de las chronicas iantigüedad de la siempre Virgen Madre de Dios, Córdoba 1598, libro VII, cap. V. 
Respecto a san Francisco fue sin duda Zurbarán quien con más contundencia tipificó el éxtasis del franciscano. En sus innumerables versiones sobre "San Francisco en meditación" (fig. 14) despliega un lenguaje mínimo pero sabiamente combinado. El mimo con el que la mano envuelve la calavera objeto de la meditación entusiasmada, en el estricto sentido del término, el gesto mitad simbólico, mitad retórico de la otra mano y la mirada hacia lo alto parecen estar insistiendo en que somos testigos de un acontecimiento sobrenatural, el que los teólogos explicaron como visión intelectual definida como aquella en la que "el ánima ve y conoce claramente lo que Dios le revela y llamase intelectual porque el entendimiento, sin que aya de por medio figuras de cosas sensibles, o imaginarias, conoce todo lo que Dios le revela ${ }^{25}$.

Finalmente, solo cabría llegar a la conclusión de que la secuencia de imágenes propuesta funciona, y funcionó, como un verdadero manual de oración en el que, al igual que los innumerables tratados escritos, se abordaron los aspectos claves de la ortodoxia católica respecto a la actitud, al lugar, a la hora y al contenido. Así contemplado, el discurso iconográfico inicia su recorrido con la sabiduría de la caducidad de la existencia humana y concluye con la revelación del místico, punto en el que acaba el tiempo de meditación a torno a la muerte, verdadero camino de perfección para el fiel barroco.

25 Fray Antonio Daza. His.urla, vida y milagros, éxtasis y revelaciones de la bienaventurada virgen sancta Juana de la Cruz... Madrid, 1610. Dice además fray Antonio que “Esta última, la intelectual, es la más principal de todas, pues es semejante a la visión que gozan los bienaventurados en la Gloria”. 